\title{
Efek Konseling Gizi terhadap Pengetahuan dan Kepatuhan Pembatasan Intake Cairan pada Pasien Chronic Kidney Disease (CKD) di RSUD Abdul Wahab Sjahranie Samarinda
}

\author{
Maulida Ulfah ${ }^{1}$, Yuniarti $^{2}$, Arintina Rahayuni ${ }^{3}$ \\ 1,2,3 Jurusan Gizi Poltekkes Kemenkes Semarang \\ Jl. Wolter Monginsidi No.115, Pedurungan Tengah, Pedurungan, Kota Semarang, Jawa Tengah 50192 \\ (Email : yuni4rti1976@yahoo.com)
}

\begin{abstract}
Background:Between 8 to $10 \%$ of the adult population suffers kidney damage and every year millions of people die from complications related to CKD. Fluidintake restrictions is the most difficult aspect to adhere, in RSUD Sukoharjo 45,16\% who do not adherence of fluid intake restrictions. Based on the results of research in RSUD Sukoharjo as much as $58,06 \%$ patients have less knowledge of fluid intake restrictions.

Objective: Know the effects of nutrition counseling to knowledge and adherence of fluid intake restrictions on CKD patients in RSUD Abdul Wahab Sjahranie Samarinda.

Methods:The type of research was quasi experiment, using pre-post test control group design. Total research subjects were 15 people treatment and 15 control people. Data analysis used to know the difference using different test.

Results:There was a significant difference in knowledge of fluid intake restrictionsbefore and after nutritional counseling using leaflets $p<0,05(p=0,001)$. There was a significant difference in adherence of fluid intake restrictionsbefore and after nutritional counseling using leaflets $p<0,001(p=0,000)$. There was a significant difference in knowledge of fluid intakerestrictions before and after nutrition counseling between treatment group and control group $p<0,05(p=0,006)$. There was no significant difference in adherence of fluid intakerestrictions before and after nutrition counseling between treatment group and control group $p>0,05(p=0,109)$.

Conclusion:Nutrition counseling can improve the knowledge and adherence of fluid intake restrictions in CKD patients undergoing Hemodialysis significantly.
\end{abstract}

Keywords:nutrition counseling, fluid intakerestrictions

\begin{abstract}
ABSTRAK
Latar Belakang: Antara 8 sampai 10\% populasi orang dewasa mengalami kerusakan ginjal dan setiap tahun jutaan orang meninggal akibat komplikasi yang berkaitan dengan CKD. Pembatasan intake cairan adalah aspek yang paling sulit untuk dipatuhi, di RSUD Sukoharjo 45,16\% yang tidak patuh pada pembatasan intake cairan. Berdasarkan hasil penelitian di RSUD Sukoharjo sebanyak $58,06 \%$ pasien memiliki pengetahuan yang kurang terhadap pembatasan intake cairan.

Tujuan: Mengetahui efek konseling gizi terhadap pengetahuan dan kepatuhan pembatasan intake cairan pada Pasien CKD yang menjalani Hemodialisis di RSUD Abdul Wahab Sjahranie Samarinda.

Metode: Jenis penelitian quasi experiment, menggunakan pre-post test control grup design. Jumlah subjek penelitian yaitu 15 orang treatment dan 15 orang kontrol. Analisis data yang digunakan untuk mengetahui perbedaan menggunakan uji beda.

Hasil: Ada perbedaan bermakna pengetahuan pembatasan intake cairan sebelum dan sesudah konseling gizi menggunakan leaflet $\mathrm{p}$ $<0,05(p=0,001)$. Ada perbedaan bermakna kepatuhan pembatasan intake cairan sebelum dan sesudah konseling gizi menggunakan leaflet $p<0,001(p=0,000)$. Ada perbedaan bermakna pengetahuan pembatasan intake cairan sebelum dan sesudah konseling gizi antara kelompok treatment dan kelompok kontrol $p<0,05(p=0,006)$. Tidak ada perbedaan bermakna kepatuhan pembatasan intake cairan sebelum dan sesudah konseling gizi antara kelompok treatment dan kelompok kontrol $p>0,05(p=0,109)$.

Kesimpulan: Konseling gizi dapat meningkatkan pengetahuan dan kepatuhan pembatasan intake cairan pada pasien CKD yang menjalani Hemodialisis secara signifikan.
\end{abstract}

Kata Kunci : konseling gizi, pembatasan intake cairan 


\section{PENDAHULUAN}

Penyakit Ginjal Kronik (PGK) atau Chronic Kidney Disease (CKD) adalah hilangnya fungsi ginjal yang progresif selama periode bulan atau tahun. Setiap ginjal memiliki nefron yaitu filter kecil yang jumlahnya sekitar satu juta. Jika sebagian nefron ini rusak dan berhenti bekerja maka nefron yang sehat mendapatkan pekerjaan tambahan, tetapi jika kerusakan terjadi secara terus menerus, maka semakin banyak nefron yang rusak. Hal ini akan mengakibatkan ginjal tidak dapat menyaring darah dengan baik'.

Global Burden of Diseasepada tahun 2010 menyatakan bahwa CKD merupakan peringkat 18 dalam daftar penyebab kematian di seluruh dunia (2). Antara 8 sampai $10 \%$ populasi orang dewasa mengalami kerusakan ginjal dan setiap tahun jutaan orang meninggal akibat komplikasi yang berkaitan dengan $\mathrm{CKD}^{2}$.

Hemodialisis (HD) merupakan terapi pengganti ginjal yang menggunakan mesin untuk menyaring darah dari luar tubuh. Pasien CKD yang menjalankan HD perlu melakukan perubahan pola makan, jumlah obat-obatan dan asupan cairan terkait dengan ginjal yang tidak berfungsi normal ${ }^{3}$.

Pasien yang pada awalnya telah diberikan penyuluhan untuk mengurangi intake cairan masih sering mengalami keluhan sesak napas saat datang untuk melakukan HD, hal ini akibat kelebihan volume cairan tubuh yaitu kenaikan melebihi dari $5 \%$ dari berat badan kering ${ }^{4}$. Data Kepatuhan terhadap pembatasan intake cairan di RSUD Arifin Achmad Pekanbaru 31,5\% sedangkan di RSUD Sukoharjo 45,16\%, hal ini menunjukkan masih banyaknya pasien CKD yang tidak patuh ${ }^{5,6}$. Ketidakpatuhan terhadap pembatasan intake cairan akan terjadi edema dan meningkatkan risiko pada kardiovaskuler dan hipertensi ${ }^{6}$. Angka kejadian edema di RSUD Abdul Wahab Sjahranie Samarinda mencapai $25 \%$ dari total pasien CKD yang menjalani HD, hal ini merupakan akibat ketidakpatuhan pasien.

Cara yang dapat digunakan untuk meningkatkan kepatuhan diet pembatasan intake cairan pasien salah satunya dengan meningkatkan pengetahuan pasien. Berdasarkan hasil penelitian di RSUD Sukoharjo sebanyak $58,06 \%$ pasien memiliki pengetahuan yang kurang terhadap pembatasan intake cairan. Pasien yang memiliki pengetahuan lebih luas diharapkan dapat mengatasi masalah yang dihadapi, percaya diri dan mudah mengikuti anjuran dari tenaga kesehatan ${ }^{4,6}$. Peningkatan pengetahuan dapat dilakukan dengan pendidikan secara individu salah satunya dengan konseling yang merupakan proses komunikasi dua $\operatorname{arah}^{7,8}$. Hal ini didukung oleh penelitian tentang pemberian pendidikan secara individu dapat meningkatkan pengetahuan pembatasan intake cairan dan penurunan IDWG pada pasien CKD yang menjalani Hemodialisis ${ }^{7}$. Ahli gizi sebagai salah satu tenaga kesehatan diharapkan mampu memberikan pelayanan rawat jalan dengan memberikan edukasi melalui konseling gizi karena dapat meningkatkan kepatuhan diet pasien ${ }^{9}$.

Berdasarkan uraian tersebut peneliti tertarik untuk melakukan konseling gizi pada Pasien CKD yang menjalani Hemodialisis untuk meningkatkan kepatuhan dalam pembatasan intake cairan di RSUD Abdul Wahab Sjahranie Samarinda. Rumah sakit ini dipilih karena merupakan rumah sakit rujukan dimana perawatan HD banyak dilakukan. Selain itu penelitian mengenai intake cairan oleh tenaga gizi belum banyak dilakukan. Hasil penelitian diharapkan dapat meningkatkan pengetahuan dan kepatuhan pasien CKD yang menjalani HD di rumah sakit tersebut.

\section{METODE}

Penelitian ini termasuk dalam penelitian di bidang gizi klinik yang mengkaji "Efek Konseling Gizi terhadap Pengetahuan dan Kepatuhan Pembatasan Intake Cairan pada Pasien Chronic Kidney Disease (CKD) yang Menjalani Hemodialisis di RSUD Abdul Wahab Sjahranie Samarinda".

Jenis penelitian ini merupakan penelitian quasi experiment, menggunakan pre-post test control grup design yaitu bentuk desain eksperimen yang menggunakan kelompok kontrol tetapi kelompok kontrolnya tidak berfungsi secara penuh untuk mengontrol variabelvariabel luar yang dapat mempengaruhinya. Melakukan rangkaian percobaan untuk mengetahui konseling gizi sebagai variabel independent terhadap pengetahuan dan kepatuhan sebagai variabel dependent. Populasi dalam penelitian ini yaitu pasien CKD yang menjalani Hemodialisis di RSUD Abdul Wahab Sjahranie Samarinda pada April 2017. Teknik pengambilan subjek penelitian dengan purposive sampling, berdasarkan kriteria inklusi yaitu IDWG (Interdialytic Weight Gain) $\geq 4 \%$; dapat makan dan berjalan tanpa bantuan; umur minimal 18 tahun dan maksimal 65 tahun; menjalani hemodialisis 2 kali dalam seminggu; bersedia menjadi subjek penelitian; tidak mengalami gangguan kognitif dan psikologi; lama hemodialisis $<2$ tahun dan kriteria eksklusi yaitu pasien meninggal dunia; pasien mengundurkan diri sebagai subjek penelitian; pasien pindah rumah sakit. Besar subjek penelitian dihitung menggunakan rumus uji hipotesis beda rata-rata pada 2 kelompok independent.

Data yang dikumpulkan pada penelitian ini adalah identitas subjek penelitian diambil dengan wawancara, data pengetahuan pembatasan intake cairan diambil melalui penilaian kuesioner, dan data kepatuhan pembatasan intake cairan diperoleh dengan cara melakukan penimbangan BB sebelum dan sesudah melakukan HD menggunakan timbangan injak digital yang kemudian menghitung IDWG pasien.

Konseling gizi merupakan proses komunikasi dua arah oleh konselor gizi dalam mengatasi masalah tentang pembatasan intake cairan yang dilakukan setiap satu minggu sekali selama tiga minggu ${ }^{10,11}$ dievaluasi melalui pengetahuan dan kepatuhan pasien, dilakukan dengan panduan menggunakan leaflet, hasil ukur tidak diberikan konseling dan diberikan konseling.

Pengetahuan pembatasan intake cairan merupakan pengetahuan pasien HD tentang intake cairan meliputi pengertian, tujuan, indikasi dilakukannnya pembatasan 
intake cairan, akibat kelebihan cairan, cara membatasi intake cairan, penilaian dilakukan sebelum treatment dan sesudah dilakukan treatment pada minggu terakhir penelitian, yang diukur menggunakan kuesioner yang sudah divalidasi dengan uji Reliability Statistics pada penelitian sebelumnya ${ }^{6}$ dengan total pertanyaan sebanyak 20 pertanyaan.

Kepatuhan pembatasan intake cairan merupakan kepatuhan pasien dalam membatasi konsumsi cairan yang dilihat dari kenaikan berat badan diantara dua waktu dialysis yaitu setelah HD pertama dan sebelum HD kedua, penilaian dilakukan sebelum treatment dan sesudah dilakukan treatment pada minggu terakhir penelitian, yang diukur menggunakan rumus

$$
\frac{B B \text { pre } H D 2-B B \text { post } H D 1}{B B \text { post } H D 1} \times 1,
$$

hasil ukurnya \%IDWG, skala ukur yang digunakan yaitu interval.

Analisis statistik yang digunakan yaitu analisis univariat dan analisis bivariat. Analisis univariat dilakukan untuk mendiskripsikan karakteristik subjek penelitian Analisis bivariat digunakan untuk melihat pengaruh masing-masing variabel independent yaitu konseling gizi, dengan variabel dependent yaitu perbedaan pengetahuan sebelum dan sesudah pada kelompok treatment dan kontrol tidak berdistribusi normal menggunakan uji Wilcoxon; perbedaan kepatuhan sebelum dan sesudah pada kelompok treatment berdistribusi normal menggunakan uji Paired T-Test; perbedaan kepatuhan sebelum dan sesudah pada kelompok kontrol tidak berdistribusi normal menggunakan uji Wilcoxon; perbedaan pengetahuan sebelum konseling gizi antara kelompok treatment dan kelompok kontrol tidak berdistribusi normal menggunakan uji Mann Whitney; perbedaan pengetahuan sesudahkonseling gizi antara kelompok treatment dan kelompok kontrol tidak berdistribusi normal menggunakan uji Mann Whitney; perbedaan kepatuhan sebelum konseling gizi antara kelompok treatment dan kelompok kontrol tidak berdistribusi normal menggunakan uji Mann Whitney; perbedaan kepatuhan sesudah konseling gizi antara kelompok treatment dan kelompok kontrol berdistribusi normal menggunakan uji Independent T-test.

\section{HASIL DAN PEMBAHASAN}

Subjek penelitian adalah pasien CKD yang menjalani Hemodialisis yaitu sebanyak 30 orang dimana terbagi menjadi dua kelompok yaitu kelompok treatment dan kelompok kontrol masing-masing sebanyak 15 orang.

Tabel 1. Distribusi Frekuensi Umur, Jenis Kelamin, Pendidikan Terakhir dan Pekerjaan Subjek Penelitian

\begin{tabular}{llllll}
\hline \multirow{2}{*}{$\begin{array}{c}\text { Variabel } \\
\mathbf{n}\end{array}$} & \multicolumn{2}{c}{ Treatment } & \multicolumn{2}{c}{ Kontrol } \\
\cline { 2 - 6 } & $\mathbf{\%}$ & $\mathbf{n}$ & $\%$ & \\
\hline Umur (Tahun) & & & & \\
$26-45$ & 4 & 26,7 & 5 & 33,3 \\
$46-65$ & 11 & 73,3 & 10 & 66,7 \\
\hline
\end{tabular}

\begin{tabular}{lllll}
\hline \multicolumn{1}{c}{$\begin{array}{c}\text { Variabel } \\
\mathbf{n}\end{array}$} & \multicolumn{2}{c}{ Treatment } & Kontrol \\
\cline { 2 - 5 } & $\%$ & $\mathbf{n}$ & $\%$ & \\
\hline Jenis Kelamin & & & & \\
$\quad$ Perempuan & 9 & 60,0 & 11 & 73,3 \\
$\quad$ Laki-laki & 6 & 40,0 & 4 & 26,7 \\
Pendidikan Terakhir & & & & \\
Tidak Sekolah/Tidak Tamat & 1 & 6,7 & 1 & 6,7 \\
SD & 4 & 26,7 & 3 & 20,0 \\
SD & 0 & 0,0 & 2 & 13,3 \\
SMP & 7 & 46,7 & 3 & 20,0 \\
SMA/SMK & 3 & 20,0 & 6 & 40,0 \\
Perguruan Tinggi & & & & \\
Pekerjaan & 0 & 0,0 & 1 & 6,7 \\
Guru & 1 & 6,7 & 1 & 6,7 \\
PNS/ABRI/POLRI & 0 & 0,0 & 1 & 6,7 \\
Karyawan Swasta & 1 & 6,7 & 0 & 0,0 \\
Pedagang & 12 & 80,0 & 11 & 73,3 \\
Tidak Bekerja & 1 & 6,7 & 1 & 6,7 \\
Lain-lain & & & & \\
\hline
\end{tabular}

Berdasarkan tabel 1 dapat diketahui bahwa umur pasien antara 46-65 tahun mendominasi pada kelompok treatment dan kelompok kontrol. Hal ini dapat dipengaruhi oleh Laju Filtrasi Glomerulus (LFG) yang mulai mengalami penurunan secara progresif pada umur diatas 40 tahun sampai 70 tahun sebanyak $\pm 50 \%$, kemampuan inilah yang mempengaruhi kerja ginjal ${ }^{12}$.Pendidikan terakhir atau tingkat pendidikan pasien memiliki kekuatan hubungan positif untuk memahami informasi dan mengaplikasikannya dalam perilaku dan gaya hidup sehari-hari yang termasuk dalam kepatuhan ${ }^{13}$.

Dari tabel 2, diketahui bahwa pengetahuan pasien tentang pembatasan intake cairan dalam kategori baik mengalami peningkatan setelah dilakukan konseling gizi menggunakan leaflet. Hal ini dapat dilihat pada jawaban dari pertanyaan yang diajukan dalam kuesioner diperoleh hasil bahwa pertanyaan yang paling banyak salah pada kelompok treatment sebelum dilakukan konseling gizi menggunakan leaflet yaitu pertanyaan "Apabila terjadi pembengkakan pada kaki atau tangan dianjurkan membatasi makanan yang mengandung gula" sebesar 60,0\%, "Makan permen, dan sikat gigi adalah cara yang dapat dilakukan untuk mengurangi rasa haus" dan "Untuk mengurangi rasa haus pasien tidak dianjurkan mengkonsumsi air dingin" masingmasing sebesar 46,7\%. Setelah dilakukan konseling menggunakan leaflet pertanyaan yang paling banyak salah pada kelompok treatmentyaitu masih pada pertanyaan yang sama hanya saja persentasenya yang menurun yaitu "Apabila terjadi pembengkakan pada kaki atau tangan dianjurkan membatasi makanan yang mengandung gula" sebesar 26,7\%, "Makan permen, dan sikat gigi adalah cara 
yang dapat dilakukan untuk mengurangi rasa haus" dan "Untuk mengurangi rasa haus pasien tidak dianjurkan mengkonsumsi air dingin" masing-masing sebesar $20,0 \%$. Kemudian pengetahuan pembatasan intake cairan dalam kategori baik mengalami peningkatan setelah diberikan leaflet pada kelompok kontrol.
Pengetahuan tentang pembatasan intake cairan pada kedua kelompok sama-sama mengalami peningkatan, namun pada kelompok treatment perubahannya jauh lebih tinggi karena dilakukan konseling gizi. Konseling gizi dapat meningkatkan pengetahuan dan kemampuan yang lebih baik ${ }^{14}$.

Tabel 2. Distribusi Frekuensi Pengetahuan dan Kepatuhan Pembatasan Intake Cairan (Pre-Post Test)

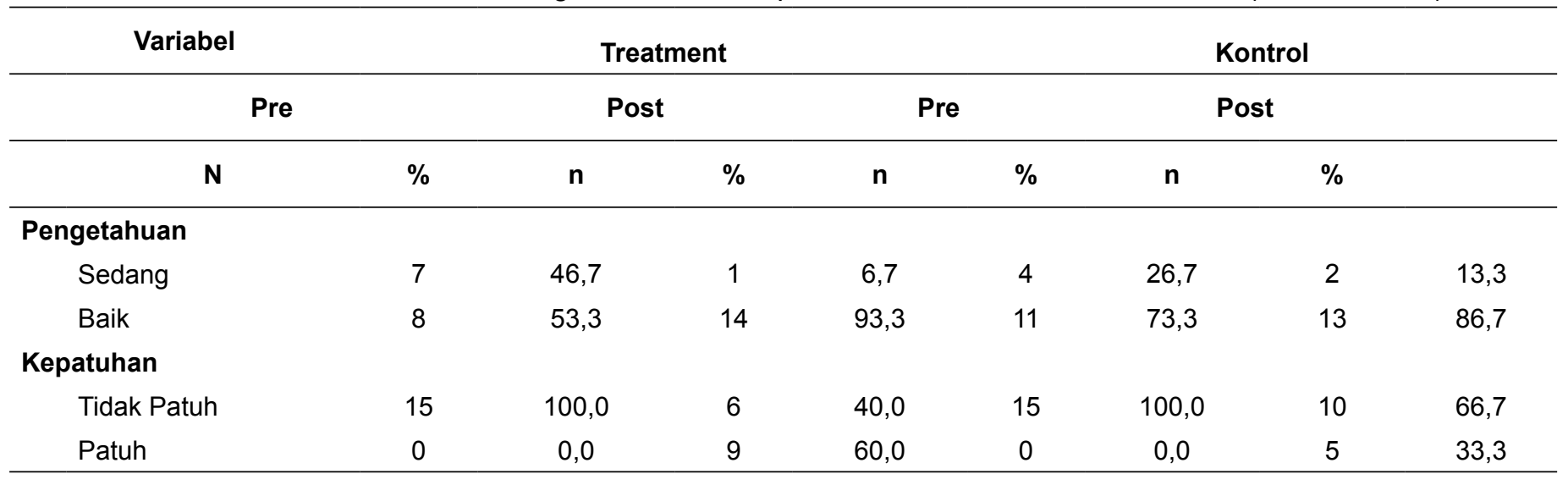

Berdasarkan tabel 2 dapat diketahui bahwa pada awal penelitian semua subjek penelitian dalam kategori tidak patuh. Kemudian setelah dilakukan konseling gizi menggunakan leaflet pada kelompok treatment, kategori patuh meningkat. Beberapa yang dikategorikan tidak patuh masih menunjukkan angka penurunan IDWG yang baik. Pada kelompok kontrol yang hanya diberikan leaflet saja, kategori patuh juga meningkat yaitu sebanyak 5 orang $(33,3 \%)$, sedangkan 10 orang $(66,7 \%)$ masih dalam kategori tidak patuh yaitu angka IDWG ada yang menurun, tetap dan ada pula yang meningkat. Hasil ini menggambarkan bahwa masih $\geq 40 \%$ subjek penelitian yang tidak patuh pada pembatasan intake cairan.

Berdasarkan hasil penelitian dapat dilihat pada tabel 3, diperoleh hasil ada perbedaan bermakna antara pengetahuan pembatasan intake cairan sebelum dan sesudah konseling gizi menggunakan leaflet $(p=0,001)$. adanya konseling gizi dapat dijadikan metode dalam mencapai tujuan komunikasi karena melibatkan pemberi dan penerima pesan secara aktif. Komunikasi yang memberikan peluang untuk saling tanya jawab, menggali informasi dan mengklarifikasi akan memudahkan dalam menerima informasi ${ }^{14}$.

Sedangkan pada kelompok kontrol diperoleh hasil ada perbedaan bermakna antara pengetahuan dan pembatasan intake cairan setelah diberikan leaflet $(p=0,008)$. Adanya perbedaan pengetahuan pembatasan intake cairan pada kelompok kontrol, menunjukkan bahwa pemberian leaflet memberikan perubahan pengetahuan pada pasien CKD yang menjalani HD. Peningkatan pengetahuan pada kelompok kontrol dimungkinkan karena subjek penelitian membacaleaflet berulang kali sehingga dapat mempercepat ingatannya ${ }^{11,15}$.

Tabel 3. Perbedaan Pengetahuan dan Kepatuhan Pembatasan Intake Cairan Sebelum dan Sesudah Konseling Gizi

\begin{tabular}{|c|c|c|c|c|c|c|}
\hline \multirow{3}{*}{ Variabel } & \multicolumn{2}{|c|}{ Treatment } & \multicolumn{4}{|c|}{ Kontrol } \\
\hline & \multicolumn{2}{|c|}{ Rata-rata $\pm S D$} & \multirow{2}{*}{$\begin{array}{l}\text { Sig } \\
\text { (p) }\end{array}$} & \multicolumn{2}{|c|}{ Rata-rata $\pm S D$} & \multirow{2}{*}{$\begin{array}{l}\text { Sig } \\
\text { (p) }\end{array}$} \\
\hline & Pre & Post & & Pre & Post & \\
\hline Pengetahuan & $81,33 \pm 9,35$ & $94,33 \pm 6,23$ & $0,001^{* *}$ & $84,33 \pm 4,95$ & $88,00 \pm 5,28$ & $0,008^{* *}$ \\
\hline Kepatuhan & $6,43 \pm 1,38$ & $4,13 \pm 1,54$ & $0,000^{*}$ & $6,47 \pm 1,90$ & $5,13 \pm 1,75$ & $0,023^{* *}$ \\
\hline
\end{tabular}
$\left.{ }^{*}\right)$ : Uji Paired T-Test
$\left({ }^{* *}\right): U j i$ Wilcoxon

Berdasarkan tabel 3, diperoleh hasil ada perbedaan antara kepatuhan pembatasan intake cairan sebelum dan sesudah konseling gizi menggunakan leaflet $(p=0,000)$.
Adanya perbedaan kepatuhan pembatasan intake cairan pada kelompok treatment, menunjukkan bahwa konseling gizi dengan menggunakan leaflet memberikan perubahan 
kepatuhan pada pasien CKD yang menjalani HD. Konseling dinilai efektif karena ada perubahan perilaku ${ }^{14}$ sehingga membawa dampak secara klinis.

Pada kelompok kontrol, ada perbedaan bermakna antara kepatuhan pembatasan intake cairan setelah diberikan leaflet $(p=0,023)$. Adanya perbedaan kepatuhan pembatasan intake cairan pada kelompok kontrol, menunjukkan bahwa pemberian leaflet memberikan perubahan kepatuhan pada pasien CKD yang menjalani HD.

Menurut Lawrence Green kepatuhan dipengaruhi oleh faktor predisposisi salah satunya yaitu tingkat pendidikan, semakin tinggi pendidikan subjek maka kepatuhan pembatasan intake cairan semakin baik ${ }^{13}$. Faktor predisposisi yang lain yaitu umur yang menunjukkan bahwa semakin tua umur pasien semakin tinggi skala demensia yang diperoleh dan semakin tinggi pula ketidakpatuhan pasien ${ }^{16,17}$. Oleh karena itu, dapat dimungkinkan pada kelompok kontrol juga mengalami peningkatan kepatuhan walaupun hanya menggunakan leaflet.

Pada awal penelitian pengetahuan tentang pembatasan intake cairan tidak berbeda pada kelompok treatment dan kontrol $(p=0,427)$. Sesudah penelitian diperoleh hasil ada perbedaan bermakna antara pengetahuan pembatasan intake cairan sebelum dan sesudah konseling gizi antara kelompok treatment dan kontrol, $(p=0,006)$. Peningkatan pengetahuan lebih besar pada kelompok treatment dibandingkan dengan kelompok kontrol (grafik pada gambar 1).

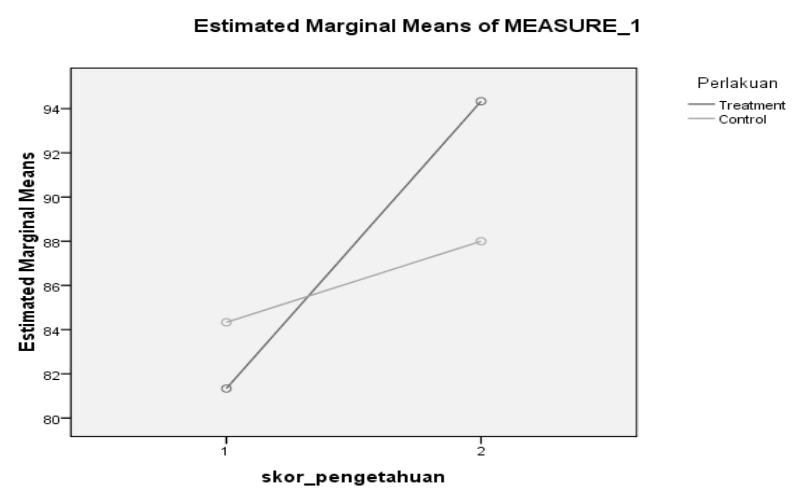

Gambar 1. Grafik Pengetahuan Pembatasan Intake Cairan antara Kelompok Treatment dan Kelompok Kontrol

Hasil ini dapat disimpulkan ada perbedaan pengetahuan secara signifikan terhadap pembatasan intake cairan sebelum dan sesudah konseling gizi antara kelompok treatment dan kelompok kontrol. Pendidikan kesehatan secara individual lebih meningkatkan pengetahuan dibanding kelompok leaflet. Hal ini karena jika diberikan secara individual menghasilkan kontak antar penerima dan pemberi pesan menjadi lebih intensif ${ }^{18}$. Sedangkan konseling merupakan salah satu cara untuk memberikan pendidikan kesehatan dengan sasaran individu dengan kedudukan atau hubungan secara horizontal, yaitu kedudukan pasien dan konselor sejajar yang diharapkan menimbulkan perasaan yang nyaman dan informasi mudah untuk diterima ${ }^{14}$.

Tabel 4. Perbedaan Pengetahuan dan Kepatuhan Pembatasan Intake Cairan Sebelum dan Sesudah Konseling Gizi antara Kelompok Treatment dan Kelompok Kontrol

\begin{tabular}{|c|c|c|c|c|c|c|}
\hline \multicolumn{4}{|c|}{ Pre } & \multicolumn{3}{|c|}{ Post } \\
\hline \multirow{2}{*}{ Variabel } & \multicolumn{2}{|c|}{ Rata-rata $\pm S D$} & \multirow{2}{*}{$\begin{array}{l}\text { Sig } \\
\text { (p) }\end{array}$} & \multicolumn{2}{|c|}{ Rata-rata $\pm S D$} & \multirow{2}{*}{$\begin{array}{l}\text { Sig } \\
\text { (p) }\end{array}$} \\
\hline & Treatment & Kontrol & & Treatment & Kontrol & \\
\hline Pengetahuan & $81,33 \pm 9,35$ & $84,33 \pm 4,95$ & $0,427^{* *}$ & $94,33 \pm 6,23$ & $88,00 \pm 5,28$ & $0,006^{* *}$ \\
\hline Kepatuhan & $6,43 \pm 1,38$ & $6,47 \pm 1,90$ & $0,619^{* *}$ & $4,13 \pm 1,54$ & $5,13 \pm 1,75$ & $0,109^{*}$ \\
\hline
\end{tabular}

$\left(^{*}\right)$ : Uji Independent T-Test $\quad\left(^{* *}\right): U j i ~ M a n n$ Whitney

Pada awal penelitian kepatuhan pembatasan intake cairan tidak berbeda pada kelompok treatment dan kontrol $(p=0,619)$. Sesudah penelitian, diperoleh hasil tidak ada perbedaan bermakna antara kepatuhan pembatasan intake cairan sebelum dan sesudah konseling gizi pada kelompok treatment dan kelompok kontrol $(p=0,109)$. Tidak adanya perbedaan antara pengetahuan pembatasan intake cairan sebelum dan sesudah konseling gizi pada kelompok treatment dan kelompok kontrol, menunjukkan bahwa kemungkinan terjadi karena pada kelompok treatment yang telah diberikan konseling masih ada yang tidak patuh pada pembatasan intake cairan yang dilihat dari IDWG pasien. Keberhasilan konseling itu sendiri tergantung dari berbagai faktor, baik faktor internal (pendidikan, keahlian, persepsi) maupun eksternal (lingkungan, organisasi, social budaya, sosioekonomi $)^{19}$. Sedangkan dalam proses konseling seseorang yang membutuhkan pertolongan (pasien) dan seorang petugas konseling akan bertatap muka dan berbicara hingga pasien mampu untuk memecahkan masalah yang dihadapinya ${ }^{14}$.

Pada penelitian ini pasien yang menjadi subjek penelitian memberikan respon yang baik dalam usaha pembatasan intake cairan yang telah disesuaikan dengan kebutuhan masing-masing pasien yaitu cairan yang masuk bergantung pada jumlah urin per 24 jam ditambah dengan IWL (500-750 ml $)^{20}$. Walaupun masih ada pasien yang tidak patuh terhadap pembatasan intake cairan pada kelompok treatment, dilihat IDWG $\geq 4 \%$. Hal ini mungkin karena pada 
pasien CKD terdapat peningkatan kadar angiotensin II yang dapat menimbulkan rasa haus, akan tetapi pasien ini tidak bisa mengelola secara normal terhadap haus yang dirasakan ${ }^{21}$.

Meskipun secara uji statistik diperoleh hasil tidak ada perbedaan bermakna antara kepatuhan pembatasan intake cairan sebelum dan sesudah konseling gizi pada kelompok treatment dan kelompok kontrol, namun terjadi peningkatan kepatuhan yang lebih tinggi pada kelompok treatment dibandingkan dengan kelompok kontrol berdasarkan penurunan IDWG yaitu dilihat dari beda rata-rata sebesar 2,3 (grafik pada gambar 2). Sehingga dengan melakukan konseling gizi menggunakan leaflet lebih baik daripada hanya memberikan leaflet saja.

Estimated Marginal Means of MEASURE_1

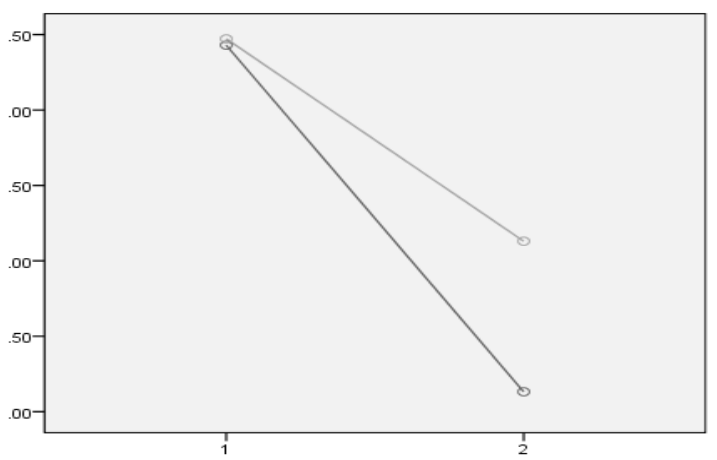

Perlakuan - Treatment

Gambar 2. Grafik Kepatuhan Pembatasan Intake Cairan antara Kelompok Treatment dan Kelompok Kontrol

\section{KESIMPULAN DAN SARAN}

Ada perbedaan pengetahuan, kepatuhan pembatasan intake cairan serta intake cairan sebelum dan sesudah konseling gizi pada Pasien CKD yang menjalani Hemodialisis di RSUD Abdul Wahab Sjahranie Samarinda. Tidak ada perbedaan kepatuhan pembatasan intake cairan sebelum dan sesudah konseling gizi antara kelompok treatment dan kontrol pasien CKD yang menjalani Hemodialisis di RSUD Abdul Wahab Sjahranie Samarindanamun terjadi peningkatan kepatuhan yang lebih tinggi pada kelompok treatment.

Perlu adanya kebijakan pemberian program intervensi konseling gizi yang berkesinambungan dengan mengatur frekuensi konseling untuk meningkatkan pengetahuan dan kepatuhan pasien

Bagi Pasien, harus memahami dan mentaati pola pembatasan intake cairan yang sesuai dengan rekomendasi ahli gizi maupun tenaga medis lainnya. Bagi Peneliti Lain perlu adanya penelitian lebih lanjut mengenai efek konseling gizi terhadap pengetahuan dan kepatuhan pembatasan intake cairan pada pasien CKD yang menjalani HD dengan memperhatikan sikap, dukungan keluarga dan dilakukan pendekatan secara longitudinal.

\section{DAFTAR PUSTAKA}

1. World Kidney Day. World Kidney Day. International Urology and Nephrology [Internet]. 2015; Available from: http://www.worldkidneyday.org/faqs/chronickidney-disease/

2. Jha V, Garcia-Garcia G, Iseki K, Li Z, Naicker S, Plattner $B$, et al. Chronic kidney disease: Global dimension and perspectives. Lancet [Internet]. 2013;382(9888):26072. Available from: http://dx.doi.org/10.1016/S01406736(13)60687-X

3. NIDDK. Treatment Methods for Kidney Failure: Hemodialysis. 2010; Available from: https://www.niddk. nih.gov/health-information/kidney-disease/kidneyfailure/hemodialysis

4. Kamaluddin R, Rahayu E. Analisis Faktor-Faktor yang Mempengaruhi Kepatuhan Asupan Cairan pada Pasien Gagal Ginjal Kronik dengan Hemodialisis di RSUD Prof. Dr. Margono Soekarjo Purwokerto. J Keperawatan Soedirman [Internet]. 2009;4(1):20-5. Available from: http://www.google.co.id/url?sa=t\&rct= $j \& q=\&$ esrc=s\&source=web\&cd=2\&cad=rja\&uact=8\&ve d=0CCUQFjAB\&url=http://jos.unsoed.ac.id/index.php/ keperawatan/article/download/175/40\&ei=K7tQVdGvl 4vi8gXHklHwAw\&usg=AFQjCNEvLx1LVFkHHyrg7Bo Mayl3dSivMw\&sig2

5. Setia Rini, Siti Rahmalia HD APD. Hubungan antara Dukungan Keluarga terhadap Kepatuhan dalam Pembatasan Asupan Nutrisi dan Cairan pada Pasien Gagal Ginjal Kronik dengan Hemodialisa. Progr Stud IImu Keperawatan Univ Riau. 2013;16-8.

6. Umayah E. Hubungan Tingkat Pendidikan, Pengetahuan dan Dukungan Keluarga dengan Kepatuhan dalam Pembatasan Asupan Cairan pada Pasien Gagal Ginjal Kronik (GGK) yang Menjalani Hemodialisa (HD) Rawat Jalan di RSUD Kabupaten Sukoharjo. Skripsi, Universitas Muhamadiyah Surakarta; 2016.

7. Hanum R, Nurchayati S, Hasneli Y. Pengaruh Pendidikan Kesehatan secara Individual tentang Pembatasan Asupan Cairan terhadap Pengetahuan tentang Pembatasan Cairan dan IDWG (Interdialytic Weight Gain) pada Pasien Hemodialisis. Jom. 2015;2(2):1427-34.

8. Kementerian Kesehatan RI. Pedoman PGRS Pelayanan Gizi Rumah Sakit. Vol. 53. Jakara; 2013. 1689-1699 $p$.

9. Sucipto A. Efektivitas Konseling DM Dalam Meningkatkan Kepatuhan Diet DM pada Diabetes Melitus Tipe 2. Med Respati. 2014;

10. Howren MB, Kellerman QD, Hillis SL, Cvengros J, Lawton W, Christensen AJ. Effect of a Behavioral SelfRegulation Intervention on Patient Adherence to FluidIntake Restrictions in Hemodialysis: a Randomized Controlled Trial. Ann Behav Med. 2016;50(2):167-76.

11. Larasari P. Pengaruh Konseling dengan Bantuan Media Leafleat terhadap Pengetahuan Penggunaan Antibiotik pada Masyarakat Patrang Kabupaten Jember. Skripsi, Universitas Jember; 2015. 
12. Anita DC, Novitasari D. Kepatuhan Pembatasan Asupan Cairan terhadap Lama Menjalani Hemodialisa. In: Prosiding Seminar Nasional \& Internasional. 2017. p. Vol. 1, No. 1.

13. Fatmah Mardjun, Zuhriana K. Yusuf AA. Faktor yang Berhubungan dengan Kepatuhan Pembatasan Asupan Cairan pada Pasien Gagal Ginjal Kronik di Ruang Hemodialisa RSUD Prof. Dr. H. Aloei Saboe Kota Gorontalo. Doctoral dissertation. Doctoral dissertation, Universitas Negeri Gorontalo; 2014.

14. Cornelia, Sumedi E dkk. Konseling Gizi. 3rd ed. Jakarta: Penebar Swadaya Grup; 2016. 9-42 p.

15. Kawuriansari R, Fajarsari D, Mulidah S. Studi Efektifitas Leaflet Terhadap Skor Pengetahuan Remaja Putri Tentang Disminorea di SMP Kristen 01 Purwokerto Kabupaten Banyumas. J Bidan Prada. 2010;1(1):10822.

16. Kugler C, Maeding I, Russell CL. Non-adherence in patients on chronic hemodialysis: An international comparison study. J Nephrol [Internet]. 2011;24(3):36675. Available from: https://www.scopus.com/inward/ record. uri?eid=2-s2.0-79955935618\& partner|D=40\&

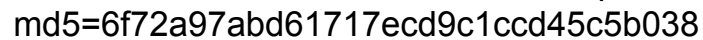

17. Hakiki AF. Analisis Faktor-Faktor yang Mempengaruhi Kepatuhan Asupan Cairan dan Nutrisi pada Klien Hemodialisis di RS PKU Muhammadiyah Yogyakarta. Doctoral dissertation. Doctoral dissertation, STIKES 'Aisyiyah Yogyakarta; 2015.

18. Notoatmodjo S. Kesehatan Masyarakat : IImu \& Seni. Jakarta: Rineka Cipta; 2007. 144 p.

19. Octa P I, Tjahjono D.K. K, Nuggetsiana S A. Pengaruh Frekuensi Konseling Gizi dan Gaya Hidup Terhadap Indeks Massa Tubuh, Lingkar Pinggang, Tekanan Darah, dan Glukosa Darah pada Penderita Diabetes Mellitus. 2011;1-19.

20. Almatsier S. Penuntun Diet. 25th ed. Almatsier S, editor. Jakarta: PT Gramedia Pustaka Utama; 2010. 178-179 p.

21. Kuniawati desak putu, Widyawati ika yuni, Mariyanti $H$. edukasi dalam meningkatkan kepatuhan intake cairan pasien penyakit ginjal kronik (PGK) on hemodialisis. 2014;1-7. 